\title{
THE FELLOWSHIP OF THE SAINTS IN CONTEMPORARY SOUTH AFRICAN SOCIETY
}

\section{INTRODUCTION}

The subject of this study is: What does the fellowship of the saints that we practise in the Church, mean to us in the present South African society. The division of the subject is as follows: Firstly an analysis of the concept fellowship of the saints; secondly some remarks about the Church in the present situation; and thirdly a closer look at the meaning the fellowship of the saints can have on our behaviour in society.

\section{THE FELLOWSHIP OF THE SAINTS}

The expression fellowship of the saints does not appear in the Bible - the concept that it expresses does, however. It is a description of the Church as added to the existing Apostolic Creed in approximately 400 A.D. : credo . . . sanctorum communionem. The correct translation of this confessional addition to the oldest creed is exceptionally difficult.

In the first place there is the problem from which noun the genetive sanctorum is derived. Is it derived from the masculine sanctus or the neuter sanctum? Is the point at issue a fellowship of or with holy persons or holy things? Is it therefore a personal or a sacramental fellowship? When holy things are referred to, sacraments or mysteries are meant; and with persons it can mean either those who are already in heaven or those who are still living on earth.

In the second place the translation of communio also entails many problems. It can denote participate in, therefore participation. The meaning of the word communio is then active. But it can also be translated in a passive sense: receive a part in, thus fellowship.

Only in the times of Charlemagne did communio receive the decisive meaning of fellowship, and sanctorum was regarded as derived from a person. The meaning would then be: the fellowship which the saints form mutually. 
In the Heidelberg Catechism answer 55, we find the fortunate combination of the old and the new meanings. Those who believe are partakers of the Lord Jesus and of all $\mathrm{His}$ riches and gifts (sancta), and everyone must know it to be his duty to employ his gifts readily and cheerfully to the advantage and salvation of other members (sanctus).

We should notice that in the explanation of the concept communio the Catechism stresses the active meaning, to participate in, and then specifically, participation in mutual relationships.

The concept "fellowship," koinonia, is in the New Testament related to Christ, as well as to the Holy Spirit. In I Cor 1 v 9 Paul speaks of the "the fellowship of His Son, Jesus Christ our Lord". The genitive is an objective genitive of the person (cf Kittel, ThWBNT III). The word fellowship is a verbal substantive ( $F$ W Grosheide) and we should actually translate it as: partake of Jesus Christ (cf Wendland, Comm I Cor).

The true believer is thus part of Christ, of what $\mathrm{He}$ has acquired, of $\mathrm{His}$ crucifix and resurrection.

Secondly the N T also relates the concept of fellowship to the Holy Spirit (II Cor 13 v 13, Phil 2 v 1). Here we should regard the genitive as a subjective genitive (cf E P Groenewald, Koinonia in Paul; F W Grosheide, Comm on II Cor $13 \mathrm{v}$ 13). The fellowship is brought about by the Holy Spirit. It is the Holy Spirit who lets us partake of Christ and of what $\mathrm{He}$ has acquired. Christ is the Origin and the Holy Spirit is the Agent of the fellowship.

As regards the verb koinooneoo there is a marked difference between the classical Greek usage and that of the New Testament. In profane Greek this verb is almost always used in its passive meaning, $i$ e you partake of somebody or something, while in the $\mathrm{N}$ T it is used in its active sense, $i$ e you give a share to somebody of something.

We find both the passive and the active usage of this verb in the $\mathrm{N} T$. When the fellowship with Christ, which is brought about by the Holy Spirit, is dealt with, the 
passive meaning of the concepts koinonia and koinooneoo is accentuated.. On the other hand when the fellowship with each other is denoted, the active sense is accentuated. Man is the giver. The same person, however, who in his relationship to Christ and the Spirit, is the receiver.

The fellowship of Christ changes into the fellowship of Christians; the fellowship with each other. We see in this transition how the passive usage of the verb koinooneoo, i e partake of, teilhaben changes into the active usage, i $e$ give part of, teilgeben (cf Kittel, ThWBNT III p 809).

In Rom $15 \mathrm{v} 26$ and 27 Paul tells of the faithful in Macedonia and Achaia who decided to make some contribution to the poor among the saints in Jerusalem. Literally the apostle wrote: to do some koinonia. In Rom $12 \mathrm{v} 13$ he calls on the faithful in Rome to contribute to the needs of the saints. The original version reads: they should practise a fellowship with the poor among the saints. Stress is laid on the action.

In Phil $4 \mathrm{v} 15$ the apostle praises the members of the Church of Philippi for entering into partnership with Paul in giving and receiving. Literally it is written as follows: the Philippians practised koinonia with him in collecting and disbursing the gifts.

In Hebr $13 \mathrm{v} 16$ the word koinonia is also used in an active sense (teilgeben, Mitteilsamkeit, Kittel, ThWBNT III p 809).

Our first conclusion is: when the common fellowship of the saints or of the faithful is dealt with in the New Testament, then stress is laid on the deed. The fellowship of the saints is an active, serving community. The believer who, compared to Christ, is in a receiving position, is in a giving position as regards his fellow brother or sister. But something still remains to be said, because in the practising of the fellowship of the saints there is a passive, receiving attitude, but we can only discuss this matter as regards the goods of the gifts with which we should serve each other and with which we should be served. 
Seperate attention should be paid to the fellowship in the Holy Communion, because it is frequently said nowadays that Communion should also be emplyed as a demonstration of our oecumenical unity. By means of the collective participation in the Holy Communion we should show the world how we are one in Christ.

When Paul uses the verb koinoneoo in I Cor 10 with reference to Holy Communion, the passive, i e that which is received, is emphasized. In I Cor $10 \mathrm{v} 16$ Paul writes about the koinonia of the body and of the blood of Christ. Here we clearly see the receiving aspect of the fellowship. This fellowship of the Holy Communion is certainly meant as a source of inspiration to form a giving, a serving, an active fellowship with regard to each other. However, nowhere in the $\mathrm{N} T$ do we find the idea that we are called upon to show our unity specifically by means of Holy Communion. If Holy Communion is remade into an active, demonstrative unity, then we disturb the nature of the fellowship. The fellowship with Christ then receives less accentuation than the fellowship with one another, as an indication to the outside world that we.heartily love each other and that we are one in Christ.

We certainly have the calling to show the world that we are one in Christ and together form one body. There is a demonstrative side to the koinonia as well, but this should not happen through Communion, but through our testimony.

In John $17 \mathrm{v} 21$ Jesus prays his often misused words: "That they may all be one, even as Thou, Father, art in Me and $I$ in Thee, that they also may be in us, so that the world may believe that Thou hast sent Me".

Christ is the missionary, the great apostle. As He was sent by the Father, so He sends his disciples into the world (v 18). As the great Missionary, sent by His Father, Christ shows the world the intimate connection with His Father. So should his disciples as sent by Christ also show the world their unity with each other and their connection with Christ. 
We see, therefore, that the world receives attention not in the Holy Communion, but with the emission.

Does this mean that white and black may not partake of Holy Communion together? Where they are members or guest-members of the same local church and when they are under the supervision of the same church council, they may partake of Holy Communion together without any objection. Holy Communion, as a sacrament, is the concern of the local church where the church council supervises the entrance to it. With the necessary permission, anybody who is a true believer, may attend Communion. This holds good for everybody, irrespective of nation or race. It should, however, never be employed as a test or a demonstration of unity to the world. As a matter of fact, the world does not enter the church to see how we celebrate Communion. We are called upon to go out in to the world. In Jesus' prayer, the cosmos means the world estranged from God (Godet; otherwise F W Grosheide who considers the cosmos to be the converts who form the real cosmos).

\section{THE PRESENT SOUTH AFRICAN SOCIETY}

With these thoughts we have actually reached the present situation of South African society. Much can be said about this situation. We can ask whether it is a Christian, a secularized or to a high degree, a pagan society. As regards our subject we should approach the situation of this society from the direction of the church. We may say that the situation of society in South Africa is multiethnic, i e multi-national. In this multi-national society we also see the miracle of the church as the fruit of missionary labour.

We have one Church, in concreto, one Reformed Church (Gereformeerde Kerk) in a multimorphous, multinational society. If we proceed from the universal nature of the Church we find in our multi-ethnic society one Church of Christ, which we confess in the Apostolic Creed.

The situation of society in South Africa, as regards the Gereformeerde Kerk, is unique. By virtue of his birth the 
reformed believer is a member of his nation. By virtue of his rebirth he is a living member of the Church. Rebirth does not cancel birth. Membership of the Church does not undo membership of the nation. Like rebirth sanctifies birth, so membership of the Church sanctifies membership of the nation.

We see therefore the one Church in Christ revealed "in countless churches scattered throughout different countries and different nations to step into the light in this way" (W J Snyman).

When we therefore examine the present situation of South African society from the point of view of the universal Church of Christ, we observe that the one Church, which here means the Gereformeerde Kerk in South Africa, is structured ethnically, viz we perceive the differences among nations mirrored in the one Church, e $g$ the language differences, cultural differences and even a marked difference in tradition and development and a difference in the experience of faith.

These differences appeared even on the birthday of the Church of the N T on Pentecost. "We hear them telling in our own tongues the mighty works of C od." (Acts $2 \mathrm{v} 11$ ). The "in our own tongues" is mentioned up to three times by Luke in the history of the outpouring of the Holy Spirit.

The Roman Catholic Church wanted to establish uniformity over the entire world by means of Latin as the language of the Church.

In the present South African situation we observe one Gereformeerde Kerk that would, if possible, assemble every five years in one General Synod. This Synod, that was founded in principle in 1964 and that met for the first time at I kageng - Potchefstroom in 1965, exists in between the two extremities of separate national churches and of one homogeneous, similar a- and anti-national world church. We find in the present South African society the institutary revelation of the unity in Christ without cancelling national varieties. 
We would like to stress that the instituting of such a General Synod is a deed of faith. In this respect we are far ahead of the other churches in this country and it should fill us with humble gratitude that this decision of faith was made after much inner conflict.

The great task of this Synod is to bring about, to preserve and cultivate the revelation of the unity of confession and of church law. Our present students of Theology will in the future, when God has instituted them in His service, be able to work on and build on that which the members of the present generation have begun.

\section{THE MEANING OF THE UNITY OF THE CHURCH FOR SOCIETY}

Unfortunately the complaint is often heard that this unity has very little meaning in our society. It is said that the unity at the "top" does not make itself felt right down to the "bottom". Although the words "top" and "bottom" are not Biblical concepts, we know nevertheless what is meant by them. The question is: How can this unity at local level and out of the Church beneficially influence society?

I want to emphasize that in my view the best service that the church can render to society consists of the church really being church. This means that the Church should display the features of the Body of Christ. We may not and should not expect the General Synod, as an institute, to exert an influence on society.

The Church will only have an influence on society when it, the Church of Christ, fulfils its calling.

The $\mathrm{N} \mathrm{T}$ teaches us that the fellowship of the saints influences a nation. Certainly the $\mathrm{N} T$ instructs us that each nation takes offence of the Gospel in its own way. Each nation utters its own special "no" to Jesus and thus crucifies Him in its own manner (cf E Stauffer, Die Theologie des N T, p 171, 174). 
There is, however, another side to the matter. Practising the fellowship by the Church impresses the nation. We read in Acts $2 \mathrm{v} 43$ that the congregation devoted themselves to the fellowship, and the result was that fear came upon every soul. The fellowship of the saints inspired the outsiders with awe. It is said in $\mathrm{v} \mathbf{4 7}$ that the congregation found favour with all the people. This was the result of the practising of the fellowship of the saints.

The $\mathrm{N} T$ also teaches us that there are two ways of practising the fellowship of the saints. I would call it an internal and an external practice of this fellowship. The local church practises the fellowship mutually as members in the church service, during the Communion, in mutual assistance and in charity.

But there was also the practice of fellowship from one congregation to another. In Gal $6 \mathrm{v} 10$ the faithful are even called upon to do good to all men, and especially to those who are of the household of faith.

A very good example of this external practice of fellowship is found in Rom $15 \mathrm{v} 26,27$. Paul speaks about the practice of koinonia across national borders. The apostle states that an exchange of good things took place. The faithful of Macedonia and Achaia have come to share the pneumatika or spiritual blessings from Palestine, and they feel in debt to the faithful in Jerusalem to be of service to them in sarkika or material blessings. In Paul pneumatika denotes Gospel while with sarkika he means material things such as food and clothing (E Sweizer, ThWBNT VII p 145).

This exchange of pneumatika and sarkika, of spiritual and material things is, according to Paul, an important form of fellowship. Therefore he calls this exchange of goods a koinonia. One church gives to the other what is lacking and it can be both material and spiritual goods.

When we ask by what means we can serve each other as churches and as true believers across national borders in the true fellowship of the saints, the answer is that the $\mathrm{N} \mathrm{T}$ 
names four ways in which we can and should serve each other.

In the first place we are called upon to serve each other with forgiveness. The willingness to forgive is one of the great services we can render each other (Matt $18 \mathrm{v} 35$ ). Therefore we shouldn't continue to feel ourselves wronged. Each nation has its own history. In many respects it may be a history of suffering and injustice. We should be willing to forgive without regard of the nation to which we belong. It is indeed a great service we can do one another. The results are a peaceful co-existence and a beautiful relationship that grows to a witness in society.

Secondly we should serve one another with Truth (Hebr $3 \mathrm{v} 13,10 \vee 34$ ). That means that we should confront one another where necessary with the truth of the Word of God and should admonish and rectify one another if necessary. This would strengthen the ties of love. We shouldn't be ashamed to mention other's clerical sins, as also the national boundaries with the Word of God there will be an ear that listens and a heart that accepts.

In the third place the $\mathrm{N} T$ shows us that we should serve each other with intercession (James 5 v 16). Pray for one another, that you may be healed and that healthful racial relationships may develop.

In the fourth place we are called upon to serve one another with charitableness (Matt $25 \mathrm{v}$ 40). We are reminded of the deacons' aid across national boundaries. There are many forms of aid, viz education, the building of churches, aid for the the aged, etc. Where we as members of churches of different nations meet, we should together, and in charity, find resourceful methods to give shape to this fourfold service to one another.

This way of practising the fellowship is not regulatable. It grows and develops and may not deteriorate into a oneway traffic. Through increased contact as local churches of different nations we shall become sensitive to each 
other's needs. We must be delivered from a one-sided, oneway traffic of spiritual and material goods from the older churches to the younger. There should be an exchange according to the needs of each.

It may be asked what the connection between this and the present situation of South African society is. I would answer everything!

This way of practising fellowship wherein the different churches send one another what is needed, will demonstrate to the world that we are one even across national boundaries, just as Christ is one with the Father. In such a koinonia we show the world our connectedness with Christ, as well as our connectedness with each other.

It is my deepest conviction that this is the basis of the solution to all our problems as regards racial relationships.

In a world full of hatred, and also of hatred between nations, we demonstrate our love, the love of Christ, and also of one another, though we do not belong to the same nation.

We belong to our nation and we love our own nation. But we belong to Christ as well and therefore we love one another, and this induces us to serve one another in the love of Christ, and in obedience to the law of the apostle. And walk in love, as Christ has loved us and gave himself up for us (Eph 5 v 2).

L FLOOR

Hammanskraal Theological Seminary 